\title{
The NBA and Youth Basketball: Recommendations for Promoting a Healthy and Positive Experience
}

\author{
John P. DiFiori ${ }^{1} \cdot$ Arne Güllich $^{2} \cdot$ Joel S. Brenner ${ }^{3} \cdot$ Jean $_{\text {Côté }}{ }^{4} \cdot$ Brian Hainline $^{5} \cdot$ Edward Ryan III $^{6} \cdot$ Robert M. Malina $^{7}$
}

Published online: 30 June 2018

(c) The Author(s) 2018

\begin{abstract}
Participation in sports offers both short-term and long-term physical and psychosocial benefits for children and adolescents. However, an overemphasis on competitive success in youth sports may limit the benefits of participation, and could increase the risk of injury, burnout, and disengagement from physical activity. The National Basketball Association and USA Basketball recently assembled a group of leading experts to share their applied research and practices to address these issues. This review includes the group's analysis of the existing body of research regarding youth sports participation and the related health, performance, and psychosocial outcomes. Based upon this, age-specific recommendations for basketball participation are provided that aim to promote a healthy and positive experience for youth basketball players.
\end{abstract}

John P. DiFiori

jdifiori@nba.com

1 Primary Care Sports Medicine, Hospital for Special Surgery, 535 East 70th Street, New York, NY 10021, USA

2 Department of Sports Science, University of Kaiserslautern, Kaiserslautern, Germany

3 Department of Pediatrics, Children's Hospital of The King's Daughters Eastern Virginia Medical School, Norfolk, VA, USA

4 School of Kinesiology and Health Studies, Queens University, Kingston, ON, Canada

5 NCAA, Indianapolis, IN, USA

6 USA Basketball, Colorado Springs, CO, USA

7 Department of Kinesiology and Health Education, University of Texas, Austin, TX, USA

\section{Key Points}

Participation in sports offers both short-term and longterm physical and psychosocial benefits for children and adolescents.

Youth should be provided opportunities and encouraged to sample different sports. They should avoid specializing in basketball prior to age 14 years.

The NBA and USA Basketball have developed agespecific guidelines for basketball participation for young athletes that are intended to promote a healthy and positive youth basketball experience.

\section{Background}

Participation in youth sports such as basketball offers many potential benefits for children and adolescents. Youth sport participation provides an avenue to develop peer relationships, self-esteem, and leadership qualities [1]. It may also lay the foundation for an active and healthier adult lifestyle [2-4]. Basketball has one of the highest rates of youth sport participation and is well suited to offer young athletes opportunities to obtain these benefits.

However, an overemphasis on competitive success in youth sports may impede children from realizing the benefits of participation, and may ultimately limit their ability 
to reach their athletic potential. Such a highly-competitive approach may be driven by desires for children to gain placement on elite travel teams, secure high school roster spots, obtain collegiate scholarships, and eventually earn professional contracts. This focus on early results rather than playing sport for enjoyment and the long-term physical and psycho-social benefits has led to several well-recognized issues:

1. Pressure to begin high-intensity training in childhood.

2. Single-sport specialization that occurs prior to adolescence.

3. Frequent and multiple competitive event scheduling.

4. Increased risk for injury, burnout, and disengagement from health-promoting physical activity both in the short term and the long term.

The idea that single-sport training at young ages increases the prospect of future sport success has been popularized in the media, but there are few scientific data to support this approach. Yet, there is a fear among parents, coaches, and young athletes that not specializing in one sport early will place the child at a competitive disadvantage. In fact, research indicates that early sport specialization is not a prerequisite and may even be detrimental to long-term achievement and elite performance [5-14]. There is also a concern that excessive focus on sport-specific intensive training and competition at a young age may impede an athlete's ability to develop transferable athletic skills, and possibly increase the risk of burnout and overuse injury, rather than optimize participation and foster interest in a variety of sports [15-20]. Regarding the relationship between injury and early single-sport specialization, the data at this time are limited and do not provide consistent evidence [21-26].

\section{Aim and Procedure}

In 2016, the Jr. NBA partnered with USA Basketball to address issues facing youth basketball in the USA. As part of this initiative, a multidisciplinary team of clinicians and researchers with expertise in athlete development and youth sports was assembled.

This group assessed the existing research related to youth sport participation, focusing on the sport of basketball. A series of seven meetings were held from May 2016 to July 2017 to review these data. From this, the recommendations for best practice in youth basketball were developed. Each recommendation was classified using the Strength of Recommendation Taxonomy system (SORT, Table 1) [27].

\section{Basketball Participation}

Basketball has high levels of participation for girls and boys across all age ranges, including recreational play and organized competition. Among US youth 6-14 years of age, 14.4 million play basketball, representing $39 \%$ of this age group [28]. Furthermore, basketball is the most popular team sport for those 12-17 years of age, with over 11 million participants. At the high school level, approximately 430,000 girls and 550,000 boys play interscholastic basketball [29]. Importantly, the top reason for playing basketball, cited by $74 \%$ of children and adolescents, is to have fun [30]. Basketball is a sport that can be modified so that it can be played informally in groupings of one, two, or three players on a side (i.e., one-on-one, two-on-two, or three-on-three). In fact, $50 \%$ of children and adolescents cite that one of the reasons they started to play basketball was because it can be played with any number of people [30]. Such recreational play is also a reason that the game can be enjoyed into adulthood. In addition, wheelchair basketball is a team sport for individuals with chronic conditions resulting in lower-limb disability such as spinal cord injury, cerebral palsy, musculoskeletal conditions, spina bifida, amputation, and poliomyelitis, and a reduced ability to play running basketball in the same manner as able-bodied players [31, 32].

\section{Basketball Promotes Healthy Youth}

In addition to the psychosocial benefits described above, youth sports can provide participants with other health benefits, including those involving the cardiorespiratory, musculoskeletal, and metabolic systems [33-39]. While physical activity is essential for healthy childhood growth and development, children in the USA and globally are not sufficiently active [40]. Recent research has shown that the development of fundamental movement skills (FMS) in children is linked
Table 1 Strength of recommendation taxonomy (SORT)

\begin{tabular}{ll}
\hline Strength of recommendation & Basis for recommendation \\
\hline A & Consistent, good-quality, patient-oriented evidence \\
B & Inconsistent or limited-quality patient-oriented evidence \\
C & Consensus, disease-oriented evidence, usual practice, expert opinion, \\
& or case series for studies of diagnosis, treatment, prevention, or \\
& screening \\
\hline
\end{tabular}


to lower levels of overweight, and higher levels of physical activity, cardiorespiratory fitness, and self-esteem [41]. Mastery of FMS such as the sprint run, vertical jump, and overarm throw, has been shown to be low [41, 42]. However, the implementation of FMS programs in schools is effective in improving FMS competencies [42].

Basketball promotes speed, agility, strength, power, endurance, flexibility, and motor coordination. As a result, basketball is uniquely oriented to improve FMS, and has been shown to be beneficial in promoting general health. In one study, basketball, along with soccer and track, provided middle school children the highest level of physical activity, regardless of the way schools offered the sport [43]. This is important in light of public health concerns related to obesity and diabetes among youth, while paradoxically, participation in school-sponsored physical education programs is low [44]. Specifically, the study suggested that basketball can effectively increase physical activity and reduce the long-term negative health consequences of an inactive lifestyle, while being an efficient option in the face of limited school resources.

Basketball can also have a positive effect on bone mineral density (BMD) for boys and girls [45-47]. A prospective study of teenage girls compared basketball players to agematched controls and found that those who played basketball had significant increases in BMD [48]. This is important since maximizing BMD at these ages provides the basis for long-term bone health throughout adulthood [49].

There is also evidence that health benefits obtained via youth sports activity can extend into adulthood [50-54]. For example, physical activity during adolescence predicts lower cardiometabolic risk in adulthood [55]. In addition, youth sport participation appears to be associated with better mental health in later life [56]. Importantly, because basketball can be modified to allow participation in various small-sided formats, it is a sport that is conducive for participation well into adulthood, thus yielding health benefits over a wide age range.

\section{Injuries in Youth Sports: How Does Basketball Compare?}

Among youth sports, basketball has a relatively low injury rate. A decade-long surveillance study of US high school sports found that basketball consistently had lower injury rates than football, wrestling, and boys' and girls' soccer [57]. With respect to overuse injuries, basketball has a relatively low injury rate at the high school level [58]. In fact, in a study of high school sports, basketball had the lowest overuse injury rate in boys and the second lowest rate in girls [58]. In addition, among female middle school athletes, basketball had a lower injury rate than both soccer and volleyball [59].

\section{Injury Risk Factors and Injury Prevention in Youth Basketball}

\subsection{Risk Factors}

Several risk factors for injury in youth sport have been identified, though data specific to basketball are limited. Prior injury, low energy availability, and training volume have been shown to be important risk factors. Previous sportrelated injury is perhaps the most-established predictor of subsequent injury [60-62]. Low energy availability, a relative deficit in energy needs, may increase the risk of bone stress injuries in both boys and girls [63, 64]. Bone stress injuries that are a result of low energy availability highlight the dangers of excessive training and competition, especially when combined with inadequate provision for re-fueling and recovery [63-65]. A weekly training time of $>16 \mathrm{~h}$ per week among 14- to 18-year-old youth has been correlated with injury risk [66-68]. As in most sports, the injury rate in basketball is greater in competition than practice $[69,70]$. In addition, youth athletes who participated in organized sports compared to peer-led play at greater than a 2:1 ratio were found to have an increased injury risk [22, 71]. However, the actual risk associated with different amounts of participation still needs validation $[22,71]$. In addition to training volume, the risk of injury may be greater during the adolescent growth spurt, though further study is needed $[15,16]$.

It is not clear if these data are generalizable to basketball or to more structured sport training settings. Research is also needed to guide long-term, sport-specific development programs.

\subsection{Injury Prevention}

Data on injury prevention programs for sports in general and for basketball in particular are limited. In addition, very little research has focused specifically on injury prevention among young athletes. Aimed at providing youth athletes with a standardized warm-up designed to prevent non-contact knee and lower extremity injuries in soccer, the original FIFA 11 program and the more recent FIFA 11+ modification have had a favorable effect in decreasing certain soccer injuries [72-75]. The program consists of 15 exercises that include running, active stretching, core strength, balance, and agility. A recent study using the FIFA 11+ program in highlevel European basketball players also reported a reduction of injury in several categories [76]. A similar neuromuscular training program has been shown to be effective in high school basketball players [77]. 
Other studies have focused on improving balance to decrease injury rates. Such studies have included adolescent and professional basketball players, and have been shown to be effective in reducing acute injuries including ankle and knee sprains, as well as back injuries [78, 79]. A program aimed at preventing hamstring injuries has been validated in soccer, but has not yet been studied in basketball [80].

Strength and conditioning programs may play a role in injury prevention as well. These programs can be safely performed by young athletes if properly implemented and supervised. In particular, preseason conditioning programs appear effective in reducing injuries [81-87].

An often-overlooked component of athlete development and injury prevention is rest. In a study of high school athletes, a $42 \%$ increase in self-reported overuse injuries was noted among those who participated all year compared to those who trained in three or fewer seasons per year [88]. At least one rest day per week, and additional periods of time away from organized sports, are recommended for physical recovery and to avoid burnout $[15,16]$. In addition, sports events or "tournaments" that involve more than one fulllength competition per day, in some cases for multiple consecutive days, may in some circumstances increase injury risk further due to the high-volume loading coupled with limited recovery time $[15,16]$.

Thus, neuromuscular training programs, including a modified FIFA 11+ program, appear promising for reducing lower extremity injuries and should be considered for broader implementation trials in youth basketball. Recent consensus statements from the American Orthopedic Society for Sports Medicine (AOSSM) and the International Olympic Committee (IOC) are supportive of such measures $[71,89]$. Measures that focus on monitoring and managing training volume-including scheduled rest and recovery, ensuring proper treatment when injuries occur, and addressing issues of relatively low energy availability and bone health-are warranted [64]. Injury prevention programs aimed at reducing hamstring injuries appear valid but need further study in basketball players.

\section{Early Single Sport Specialization-The Road to Success?}

Single sport specialization can be defined as intensive yearround training in one sport to the exclusion of others [90]. A perception exists among parents, athletes, and coaches that early single-sport specialization is necessary for longterm success. This can lead to a focus on short-term results at young ages rather than the overall development process.

The concept of early sport specialization was popularized in the USA more than 20 years ago based upon studies of chess players and musicians, but not athletes [91]. The central tenet of this model is that an individual's ultimate level of performance is directly related to the accumulated amount of deliberate practice (DP). The authors advocated the maximization of DP, which implies an early start, intensification, and subsequent expansion of DP. It was suggested that 10 years of DP is needed to achieve the highest performance levels [91].

In contrast, the state of empirical research in athletes does not provide much support for these perceptions. Several studies have shown that competitive success at the youth level correlates modestly at best, or not at all, with long-term senior success [8, 9, 92-94]. That is, early success has been described as neither a necessary precondition nor a valid predictor of long-term success.

A recent review highlighted that the participation patterns that likely lead to youth success are not the same as those that facilitate long-term development and adult success [95]. Short-term youth success is indeed correlated with early single sport specialization and intensified, sport-specific practice/training during childhood (age $\leq 12$ years) and adolescence (13-18 years) [9, 96-102]. In contrast, adult world-class athletes from all Olympic sports and different countries typically engaged in only moderate levels of early practice/training intensity in their respective primary sport. Reports of world-class athletes in basketball, field hockey, and soccer show that they attained international success accumulating much less than 10,000 practice $h$, specifically $4000-4500 \mathrm{~h}[11,12$, 81]. In this context, world-class athletes (e.g., Olympic and World Champions, medalists or top-ten athletes) did not differ from national-class peers in terms of the amount of sport-specific youth practice/training $[5,9,11,12,95$, 103-105]. Interestingly, several studies indicate that eventual world class athletes had a relatively lower level of sport-specific training during childhood [5, 9, 103, 106]. Further, international-level performers typically participated in a diverse set of sport activities, including peer-led play, and organized practice in various sports. Importantly, world-class athletes were more likely than national-class peers to engage in multiple sports $[13,95,106]$. These athletes specialized in their primary sport significantly later than their national-class peers $[5,9-12,106]$. These findings have been confirmed even when comparing Olympic and World Championship medalists to non-medalists [13, 106]. These findings were also consistent across different countries and types of sports, and were confirmed in a 3 -year prospective study [9].

Further, closer scrutiny of the "micro-structure" of practice of German world-class soccer players highlighted the significance of play. Within their total childhood soccer activities, only $14 \%$ involved drill-like training of technical skills or physical conditioning. As much as $86 \%$ was a combination of coach-led play (17\%; including conditioned, 
small-sided games), and peer-led play (69\%; "kicking around with friends") [11].

These observations do not diminish the critical significance of organized sport-specific practice on specific skill development. However, it should be recognized and placed into perspective that early reinforced intensification and specialization is unnecessary and may even be detrimental to long-term success. Alternatively, the interaction of sportspecific practice with multisport practice and play facilitates long-term development [9, 17, 19, 90, 106, 107].

The preceding discussion presumably relies on the interplay of three processes. First, in addition to training volume per se, single-sport specialization may constitute an independent risk factor of overuse injury. Diversified involvement may reduce susceptibility to overuse injury, presumably due to less cumulative stereotypical mechanical impact on certain tissues and may promote prolonged participation [15, 17, 19, 22, 24, 90, 107]. Second, youth who have explored various sports may make the decision to invest in one primary sport based on their own experiences in different sports. This likely enhances the probability that a child or adolescent elects a primary sport that optimally "fits" him or her (where "optimal fit" may represent talent at a particular sport, experienced performance progress, enjoyment, health, social interaction, etc.) [8,9]. Third, physical conditioning and perceptual-motor and psychological skills can be directly transferred across related sports [108-112]. Perhaps more importantly, early variable learning experiences improve the efficacy of (later) practice within the primary sport (greater performance improvement per invested practice time) $[5,9,11,12,14,106,113]$. Athletes acquire a multifaceted repertoire in terms of a wider and closer-meshed "network" of perceptual-motor skills, which facilitates the emergence of functional skill solutions [95, 114]. Play, in particular, unlike drill-like practice exercises, involves the interaction of situation dynamics, perception, and motor solutions, and also provides extensive implicit skill learning. This may lead to more robust skills exhibiting less susceptibility to physiological or psychological stress and better retention [115, 116]. Peer-led play, for its part, may further amplify tasks and situations (playing different roles/positions, varying rules, surfaces, court sizes, balls, number and skill level of participants) [95]. Moreover, exploring varying practice designs and learning modes can facilitate the development of individual functional learning solutions, leading to more adaptive, "smarter learners" [95, $106,113]$. In this context, it is important to note that the multisport participation of world-class athletes constituted authentic experiences in that it typically included multi-year competition-related engagement-i.e. long-term dedicated, performance-related learning processes with specialist coaches in broadened ranges of tasks and situations $[9,11$, $12,14,106]$.
Consistent with this discussion, a number of reviews and position statements have highlighted the potentially negative effects of early specialization and the positive impact of diversified youth experiences among sports and settings [13, $15,16,71,83,90,117-124]$. This reinforces the idea that childhood/adolescence multisport engagement facilitates long-term performance development-in association with positive health and psychosocial development. At the program and sport system level, this contributes to the growth of prolonged youth sport participation and expands the potential pool of talented youth athletes. In contrast, reinforcing early specialization likely diminishes general participation and the "talent pool."

\section{Personal Engagement as a Model for a Positive and Successful Youth Basketball Experience}

The findings described above have also been highlighted in applied frameworks informing policy-makers and stakeholders of the sport system, such as FTEM (Foundations, Talent, Elite, Mastery) or the DMSP (Developmental Model of Sport Participation) [6, 118, 125, 126]. The practitionerderived FTEM highlights the socio-environmental, organizational, and sport-system requirements and applications, while the DMSP more particularly looks into the psychosocial influences and outcomes in terms of positive youth development. Both frameworks emphasize the foundational role of early diversified involvement for either developing sporting excellence or prolonged recreational engagement. This section focuses on the DMSP.

The DMSP posits that personal engagement in sport grows from involvement in sport activities, relationships, and environments that evolve throughout development [127]. Combining personal engagement in sport with early sport sampling promotes a rewarding youth experience and longterm sport success [128]. For either recreational or competitive basketball, personal engagement is a primary objective of participation during youth. For this to occur, resources to develop personal meaning are needed, including: access to appropriate sport environments and role models; activities that provide personal relevance; a positive social climate; encouragement in the face of difficulty; opportunities for leadership, challenge, and knowledge-building; and opportunities to feel in-control, competent, and connected with others [129-134].

Within the DMSP, the sampling years lay an important foundation for youth to achieve optimal outcomes in sport over time [130]. Sampling generally begins during childhood, and is characterized by participation in a variety of different sports, as well as different activities within a given sport (e.g., peer-led play, organized coach-led practice). 
Following the sampling years, athletes may continue to participate in sport at a recreational level or begin to invest more and perhaps specialize in one sport during adolescence or later.

At any stage within the DMSP, youth may choose to disengage from sport; however, nurturing individual capacities for personal engagement throughout development enhances opportunities for physical and psychosocial development. By focusing on the personal, social, and physical features of different activities (e.g., interest, play, practice, sampling, specialization) across development, the DMSP suggests that the positive outcomes of sport result from the integration of processes that include personal engagement in a sport activity, the social relationships that are formed within this activity, and the physical environment in which this activity takes place [135]. More recently, the features of the DMSP have been integrated with previous youth sport research and principles from developmental systems theories to create the Personal Assets Framework for sport (PAF) [136-138].

The PAF is, in essence, a set of key elements that should be combined to provide quality sport programs for youth that not only contribute in a positive way to the overall development and well-being of the person, but also to the development of talent in sport. In line with developmental systems theories, the PAF considers personal (i.e., personal engagement in activities), relational (i.e., quality relationships), and environmental factors (i.e., appropriate social and physical settings) as the elements necessary to understand the mechanisms through which development occurs in and through sport. The interaction of the three dynamic elements constitutes a specific sport experience-for example, a game, practice, or team social activity. When repeated over a period of time, such as the span of one season, the specific sport experiences generate changes in an athlete's personal assets (e.g., confidence, competence, connection, and character) and provide personal meaning to the sport being practiced. Eventually, changes in the personal assets will influence the long-term outcomes of sport in relation to the individual's participation, performance, and personal development [139, 140].

The PAF highlights the dynamic elements and personal assets that should be combined in youth basketball programs that promote performance, participation, and personal development. Different lines of research on sport expertise and youth sport demonstrate that the objective of elite performance and continued participation are not mutually exclusive during childhood and that effectively designed sport programs for children can contribute to the overall development of youth in sport [141].

Two concepts regarding sport involvement throughout the lifespan consistently emerged from the empirical data that support an early sampling approach: diversity and peer-led play [136]. Firstly, the concept of diversity describes a level of involvement in different types of sport experiences during childhood (e.g., participating in different sport activities, or playing different positions within a sport activity), before specializing and intense training in one sport. Secondly, the concept of peer-led play relates to the notion that elite-level athletes engaged in sport activities during childhood that were inherently enjoyable and differed from organized sport and adult-led practices [136]. Peer-led sport-play activities represent a distinctive form of sport activities that add to the breadth of contexts and experiences of the youth sport environment. Together, the concepts of diversity and peer-led play form the backbone of the sampling years and may have a protective effect against burnout, dropout, and/or injuries [17-19, 142].

At a population level, youth sport programs that focus on diversity before specialization and play before practice may better maximize the potential impact that youth sport activities can have on youth development and long-term performance in sport. As suggested by the different pathways of the DMSP, the diversity and play aspect of sport activities during the sampling years should not be viewed as a discriminating factor that predicts sport expertise, but rather as a foundation for optimal development in an elite performance or recreational pathway. The nurturing of talent through sampling without an intense focus on performance in one sport during childhood can have more positive outcomes and less negative consequences for all children involved in sport, while still facilitating the development of expertise.

\section{Growth, Maturation, and Readiness for Basketball}

Sport readiness is the relationship between a child's stage of growth and development and the physical and cognitive requirements of that sport [143]. Understanding that motor skills as well as social and emotional development influence a young athlete's ability to perform physical tasks and to understand instructions is essential to promote a rewarding experience. Given inter-individual variability, chronologic age is not a reliable marker for these development levels [15].

It is clear that if a child is expected to learn too many skills that are beyond his or her ability, the child may become less motivated to learn new skills, and may eventually cease participation in the sport [144]. Conversely, a child who begins to master new tasks will develop a feeling of competence that may motivate further skill acquisition, and further interest in the sport [143].

Coaches and parents who are not aware of these issues may unintentionally create unrealistic expectations that can cause children and adolescents to feel as if they are not making progress, especially compared to chronological peers 
Table 2 Recommendations for youth basketball participation

\begin{tabular}{|c|c|c|}
\hline Topic & Recommendation & Strength $^{\mathrm{a}}$ \\
\hline Personal engagement & $\begin{array}{l}\text { Promotion of personal engagement should be a priority in youth basketball. Sport programs } \\
\text { that invest in providing opportunities for youth to connect with others, build relationships, } \\
\text { and take on challenges and leadership roles promote overall personal development, well- } \\
\text { being, and talent development }\end{array}$ & $\mathrm{B}$ \\
\hline $\begin{array}{l}\text { Multisport engagement and delayed } \\
\text { specialization }\end{array}$ & $\begin{array}{l}\text { Youth should be provided opportunities and be encouraged to engage in diverse sports and } \\
\text { delay single-sport specialization. Multisport engagement through childhood and adolescence } \\
\text { is associated with reduced risks of overuse injury, and facilitates prolonged participation, } \\
\text { psychosocial development, as well as long-term talent development. World-class athletes } \\
\text { in basketball and other sports often delayed single-sport specialization until age } 16 \text { years or } \\
\text { later. It is recommended that specialization for basketball be delayed until this age. However, } \\
\text { given that the age of high-school entry in the USA is typically age } 14 \text { years, the working } \\
\text { group recognizes that specialization may occur at this time. However, specialization prior to } \\
\text { age } 14 \text { years is discouraged }\end{array}$ & $\mathrm{B}$ \\
\hline Varied settings & $\begin{array}{l}\text { Youth should be provided opportunities and be encouraged to engage in both organized, coach- } \\
\text { led basketball activities and peer-led play. Peer-led basketball play allows youngsters to } \\
\text { experience largely self-determined, intrinsically motivated activity, be creative and challenge } \\
\text { themselves. It may contribute to individual growth and long-term talent development }\end{array}$ & $\mathrm{B}$ \\
\hline Rest and time off & $\begin{array}{l}\text { Coaches and parents should ensure sufficient rest and time away from organized basketball } \\
\text { practices and competitions. It is recommended to ensure a minimum of one day of rest each } \\
\text { week and multiple months per year away from organized basketball. Proper daily sleep, rest } \\
\text { days, and off-periods provide physical recovery, reduce injury risks, and further psychologi- } \\
\text { cal recharging }\end{array}$ & $\mathrm{C}$ \\
\hline Competition density and cumulation & $\begin{array}{l}\text { Cumulative, high-density competitions should be avoided. High-density competition scheduling } \\
\text { may increase injury risk and fatigue, and lead to loss of motivation. Parents, coaches, event } \\
\text { directors and administrators should be cautious in designing basketball events. The working } \\
\text { group recommends a maximum of two games per week per player through childhood, and a } \\
\text { maximum of three games per week through late adolescence. The working group also recom- } \\
\text { mends reducing game duration for tournaments or events during which multiple high-density } \\
\text { competitions are scheduled (i.e., reduce the number of minutes per game). "Rest games," } \\
\text { where some players are rested while their teammates compete, together with larger roster } \\
\text { sizes, will allow teams to participate without overloading individual players }\end{array}$ & $\mathrm{C}$ \\
\hline Injury prevention programs & $\begin{array}{l}\text { Neuromuscular injury prevention programs should be implemented and evaluated. Such } \\
\text { programs have been shown to reduce lower extremity injury. However, further evaluation of } \\
\text { basketball-specific programs is warranted }\end{array}$ & $\mathrm{B}$ \\
\hline Sport readiness & $\begin{array}{l}\text { Parents and coaches should adjust demands to the individual player's development. Individu- } \\
\text { als develop at different rates. Moreover, through adolescence in particular, physical, motor, } \\
\text { cognitive, emotional, and social development may proceed asynchronously within one player. } \\
\text { Carefully adjusting expectations and demands to the individual player's development furthers } \\
\text { a rewarding experience, progress in learning, motivation, and a healthy life balance }\end{array}$ & $\mathrm{B}$ \\
\hline
\end{tabular}

${ }^{a}$ Each recommendation in this table has been classified using the Strength of Recommendation Taxonomy system (SORT) defined in Table 1 [27]. Recommendations of strength B are based on inconsistent or limited-quality patient-oriented evidence and recommendations of strength C are based on expert opinion consensus

Table 3 Recommended participation guidelines

\begin{tabular}{lllll}
\hline Age (years) or grade & $\begin{array}{l}\text { Game length } \\
\text { (min) }\end{array}$ & $\begin{array}{l}\text { No. of games per } \\
\text { week }\end{array}$ & $\begin{array}{l}\text { Practice length } \\
\text { (min) }\end{array}$ & $\begin{array}{l}\text { No. of } \\
\text { practices per } \\
\text { week }\end{array}$ \\
\hline Ages 7-8 & $20-28$ & 1 & $30-60$ & 1 \\
Ages 9-11 & $24-32$ & $1-2$ & $45-75$ & 2 \\
Ages 12-14 & $28-32$ & 2 & $60-90$ & $2-4$ \\
Grades 9-12 & $32-40$ & $2-3$ & $90-120$ & $3-4$ \\
\hline
\end{tabular}

who may simply be at a different stage of growth and maturation. This, in turn, can result in loss of self-esteem and sport discontinuation [144].
Although there is no straightforward way to determine if a child is ready for basketball or another sport, important factors to consider include sport-related skills, knowledge 
Table 4 Maximum participation guidelines

\begin{tabular}{lll}
\hline Age (years) or grade & $\begin{array}{l}\text { No. of games } \\
\text { per day }\end{array}$ & $\begin{array}{l}\text { No. of hours per week } \\
\text { in organized basketball }\end{array}$ \\
\hline Ages 7-8 & 1 & 3 \\
Ages 9-11 & $2^{\mathrm{b}}$ & 5 \\
Ages 12-14 & $2^{\mathrm{b}}$ & $10^{\mathrm{c}}$ \\
Grades 9-12 & $2^{\mathrm{b}}$ & $14^{\mathrm{c}}$ \\
\hline
\end{tabular}

${ }^{a}$ Organized basketball includes game competition and practice time and structured training in which an athlete works in a focused way to improve his or her game, typically with or at the direction of a coach. Unstructured peer-led on-court activities do not constitute organized basketball for the purpose of this table (e.g., pickup games, a player shooting baskets by themselves, a player working with a peer to practice a skill). Youth basketball camps can be a positive experience for young players. Camp program content and duration is variable and may exceed the practice guidelines above. Camp directors should, however, keep the above guidelines in mind, and seek to include activities other than on-court basketball as well as rest days. The research team also recommend additional rest days following camp attendance. Residential youth sport academies also exist, particularly outside the USA. Studies in Europe point to earlier specialization, enhanced specific practice intensity and increased risks of impaired well-being, health and academic performance in the sport-students [147]. Therefore, attention to these issues is warranted. As such, academy directors and coaches should recognize the risks of early specialization and benefits of diversified participation. Their sport curricula should involve activities other than basketball to a significant portion up to age 14 years or beyond, including both organized and non-organized settings

b Youth basketball players, parents, and coaches should demonstrate caution in scheduling or participating in more than one game per day, especially on consecutive days. If young athletes participate in an event or tournament in which more than one game is played per day on consecutive days, players should have additional time off from sports activities following the event to allow for recovery

${ }^{c}$ It is recommended that young athletes in these age ranges who are approaching the maximum recommended hour limits do not participate in another sport concurrently

about the sport, motivation, and socialization [142, 145]. Parents and youth coaches should recognize the need to nurture young athletes. It is important to appreciate that even for talented individuals, the ups and downs along the path might be more related to biological maturation than to specific coaching and training techniques [123].

\section{Conclusions}

Basketball, both competitive and recreational, is a sport that has many positive attributes with respect to health and wellness. It involves moderate to high levels of sustained activity, has a relatively low injury rate, engenders positive psychosocial interactions, and is perceived as a fun game to play. The last point is significant in that it encourages long-term involvement, which in turn provides for benefits that extend into adulthood.

\subsection{Recommendations}

Based upon the preceding review of the literature and the consensus of this working group, the NBA and USA Basketball offer the recommendations described in Table 2 for young athletes, parents, coaches, and basketball organizations. Each recommendation is graded using the SORT system [27].

The following guidelines (Tables 3, 4, 5) are based upon the consensus recommendations of the NBA and USA Basketball working groups on Playing Standards and Health \& Wellness. These guidelines draw on the available scientific evidence at this time, as well as the expert opinion of the working groups and current and former men's and women's players, coaches, and administrators from all levels of basketball. These recommendations may need to be updated as new research and information develops.

\subsection{Implementation and Future Directions}

The NBA and USA Basketball are committed to driving positive change in youth basketball that promotes a healthy and positive experience for players. Efforts aimed at the grass roots level is essential for this to occur. To achieve this, these guidelines are now being implemented across their youth programming, and they have partnered with key organizations across youth basketball to similarly endorse and adopt the guidelines. Further, the NBA launched in October 2017 the Jr. NBA Flagship Network to provide a more consistent and positive youth basketball experience for players, parents, and coaches. Members of the network include 15

Table 5 Rest guidelines

\begin{tabular}{llll}
\hline Age (years) or grade & $\begin{array}{l}\text { Minimum no. of rest } \\
\text { days per week }\end{array}$ & $\begin{array}{l}\text { Maximum months per year in } \\
\text { organized basketball }\end{array}$ & $\begin{array}{l}\text { Recommended hours of } \\
\text { sleep per night [148] }\end{array}$ \\
\hline Ages 7-8 & 2 & 4 & $9-12$ \\
Ages 9-11 & 2 & 5 & $9-12$ \\
Ages 12-14 & 1 & 7 & $8-10^{\mathrm{a}}$ \\
Grades 9-12 & 1 & $9-10$ & $8-10$ \\
\hline
\end{tabular}

${ }^{\mathrm{a}}$ For 12 -year-olds, $9-12 \mathrm{~h}$ of sleep is recommended 
best-in-class organizations that share the Jr. NBA's vision for how the game should be taught and played at the grassroots level [146]. They have committed to adhering to NBA and USA Basketball Youth Guidelines, including USA Basketball coach licensing requirements and providing resources to educate coaches and parents. Finally, the NBA and USA Basketball have begun to assess the extent of basketball participation among youth, the adoption of the basketball guidelines, and the response to this initiative in youth basketball.

\section{Compliance with Ethical Standards}

Funding No sources of funding were used to assist in the preparation of this article.

Conflict of interest John DiFiori is the NBA Director of Sports Medicine. Brian Hainline is the Chief Medical Officer of the NCAA. Edward Ryan III is an athletic trainer for USA Basketball. Arne Güllich, Joel Brenner, Jean Côté, and Robert Malina declare that they have no conflicts of interest relevant to the content of this review.

Open Access This article is distributed under the terms of the Creative Commons Attribution 4.0 International License (http://creativeco mmons.org/licenses/by/4.0/), which permits unrestricted use, distribution, and reproduction in any medium, provided you give appropriate credit to the original author(s) and the source, provide a link to the Creative Commons license, and indicate if changes were made.

\section{References}

1. Fraser-Thomas J, Côté J, Deakin J. Youth sport programs: an avenue to foster positive youth development. Phys Educ Sport Pedagog. 2005;10(1):49-70.

2. McCabe KO, Modecki KL, Barber BL. Participation in organized activities protects against adolescents' risky substance use, even beyond development in conscientiousness. J Youth Adolesc. 2016. https://doi.org/10.1007/s10964-016-0454-x (Epub ahead of print).

3. Vella SA, Cliff DP, Magee CA, Okely AD. Sports participation and parent-reported health-related quality of life in children: longitudinal associations. J Pediatr. 2014;164(6):1469-74.

4. Dobosz RP, Beaty LA. The relationship between athletic participation and high school students' leadership ability. Adolescence. 1999;34(133):215-20.

5. Carlson RC. The socialization of elite tennis players in Sweden: an analysis of the players' backgrounds and development. Sociol Sport J. 1988;5:241-56.

6. Côté J, Baker J, Abernethy B. From play to practice: a developmental framework for the acquisition of expertise in team sport. In: Starkes J, Ericsson KA, editors. The development of elite athletes: recent advances in research on sport expertise. Champaign, IL: Human Kinetics; 2003. p. 89-113.

7. Baker J, Côté J, Deakin J. Expertise in ultra-endurance triathletes early sport involvement, training structure, and the theory of deliberate practice. J Appl Sport Psychol. 2005;17:64-78.

8. Vaeyens R, Güllich A, Warr CR, Philippaerts R. Talent identification and promotion programmes of Olympic athletes. J Sports Sci. 2009;27(13):1367-80.
9. Güllich A, Emrich E. Considering long-term sustainability in the development of world class success. Eur J Sport Sci. 2014;14(Suppl. 1):S383-97.

10. Güllich A, Emrich E. Evaluation of the support of young athletes in the elite sport system. Eur J Sport Soc. 2006;3:85-108.

11. Hornig M, Aust F, Güllich A. Practice and play in the development of German top-level professional football players. Eur J Sport Sci. 2016;16(1):96-105.

12. Güllich A. Many roads lead to Rome-developmental paths to Olympic gold in men's field hockey. Eur J Sport Sci. 2014;14(8):763-71.

13. Rees T, Hardy L, Güllich A, et al. The Great British medalists project: a review of current knowledge on the development of the world's best sporting talent. Sports Med. 2016;46(8):1041-58.

14. Güllich A. Sport-specific and non-specific practice of strong and weak responders in junior and senior elite athletics-a matchedpairs analysis. J Sports Sci. 2018. https://doi.org/10.1080/02640 414.2018.1449089 (Epub ahead of print).

15. DiFiori JP, Benjamin HJ, Brenner J, et al. Overuse injuries and burnout in youth sports: a position statement from the American Medical Society for Sports Medicine. Clin J Sport Med. 2014;24:3-20.

16. Brenner JS, Small EW, Bernhardt DT, et al. American Academy of Pediatrics Council on Sports Medicine and Fitness. Pediatrics. 2007;119(6):1242-5.

17. Fraser-Thomas J, Côté J, Deakin J. Examining adolescent sport dropout and prolonged engagement from a developmental perspective. J Appl Sport Psychol. 2008;20:318-33.

18. Law MP, Côté J, Ericsson KA. Characteristics of expert development in rhythmic gymnastics: a retrospective study. Int J Sport Exerc Psychol. 2007;5:82-103.

19. Wall M, Côté J. Developmental activities that lead to drop out and investment in sport. Phys Educ Sport Pedagog. 2007;12:77-87.

20. Strachan L, Côté J, Deakin J. "Specializers" versus "samplers" in youth sport: comparing experiences and outcomes. Sport Psychol. 2009;23:77-92.

21. Bell DR, Post EG, Trigsted SM, Hetzel S, McGuine TA, Brooks MA. Prevalence of sport specialization in high school athletics: a 1-year observational study. Am J Sports Med. 2016. https://doi. org/10.1177/0363546516629943 (Epub ahead of print).

22. Jayanthi NA, LaBella CR, Fischer D, Pasulka J, Dugas LR. Sports-specialized intensive training and the risk of injury in young athletes: a clinical case-control study. Am J Sports Med. 2015;43:794-801.

23. Visnes H, Aandahl HÅ, Bahr R. Jumper's knee paradox-jumping ability is a risk factor for developing jumper's knee: a 5-year prospective study. Br J Sports Med. 2013;47(8):503-7.

24. Hall R, Barber Foss K, Hewett TE, Myer GD. Sport specialization's association with an increased risk of developing anterior knee pain in adolescent female athletes. J Sport Rehabil. 2015;24(1):31-5.

25. Kahlenberg CA, Nair R, Monroe E, Terry MA, Edwards SL. Incidence of injury based on sports participation in high school athletes. Phys Sportsmed. 2016. https://doi.org/10.1080/00913 847.2016.1180269 (Epub ahead of print).

26. Fabricant PD, Lakomkin N, Sugimoto D, Tepolt FA, Stracciolini A, Kocher MS. Youth sports specialization and musculoskeletal injury: a systematic review of the literature. Phys Sportsmed. 2016. https://doi.org/10.1080/00913847.2016.1177476 (Epub ahead of print).

27. Ebell MH, Siwek J, Weiss BD, Woolf SH, Susman J, Ewigman B, et al. Strength of recommendation taxonomy (SORT): a patientcentered approach to grading evidence in the medical literature. J Am Board Fam Pract. 2004;17(1):59-67. 
28. Simmons Research. Simmons National Consumer Survey. Spring 2017. https://www.simmonsresearch.com/. Accessed 17 Jan 2017.

29. National Federation of State High School Association. 2016-17 high school athletics participation survey. http://www.nfhs.org.

30. Internal NBA Survey Data.

31. International wheelchair basketball federation official player classification manual. Winnipeg: IWBF; 2014.

32. Paulson T, Goosey-Tolfrey V. Current perspectives on profiling and enhancing wheelchair court-sport performance. Int $\mathrm{J}$ Sports Physiol Perform. 2017;12(3):275-83.

33. Smith JJ, Eather N, Morgan PJ, Plotnikoff RC, Faigenbaum AD, Lubans DR. The health benefits of muscular fitness for children and adolescents: a systematic review and meta-analysis. Sports Med. 2014;44(9):1209-23.

34. Ortega F, Ruiz J, Castillo M, et al. Physical fitness in childhood and adolescence: a powerful marker of health. Int J Obes. 2008;32(1):1-11.

35. Ortega FB, Artero EG, Ruiz JR, et al. Physical fitness levels among European adolescents: the HELENA study. Br J Sports Med. 2011;45(1):20-9.

36. Tenforde AS, Fredericson M. Influence of sports participation on bone health in the young athlete: a review of the literature. PM R. 2011;3(9):861-7.

37. U.S. Department of Health and Human Services. 2008 Physical activity guidelines for Americans: be active, healthy, and happy! http://www.health.gov/paguidelines. Accessed 17 Jan 2017.

38. White House Task Force on Childhood Obesity Report to the President. 2010. http://www.letsmove.gov/obesitytaskforc e.php. Accessed 17 Jan 2017.

39. Strong WB, Malina RM, Blimkie C, Daniels S, Dishman R, Gutin B, et al. Evidence based physical activity for school-age youth. J Pediatr. 2005;146(6):732-7.

40. Janssen I, Leblanc AG. Systematic review of the health benefits of physical activity and fitness in school-aged children and youth. Int J Behav Nutr Phys Act. 2010;7:40.

41. Hardy LL, Barnett L, Espinel P, Okely AD. Thirteen-year trends in child and adolescent fundamental movement skills: 19972010. Med Sci Sports Exerc. 2013;45(10):1965-70.

42. Morgan PJ, Barnett LM, Cliff DP, Okely AD, Scott HA, Cohen KE, et al. Fundamental movement skill interventions in youth: a systematic review and meta-analysis. Pediatrics. 2013;132(5):e1361-83.

43. Bocarro JN, Kanters MA, Edwards MB, Casper JM, McKenzie TL. Prioritizing school intramural and interscholastic programs based on observed physical activity. Am J Health Promot. 2014;28(3 Suppl):S65-71.

44. Kann L, Kinchen S, Shanklin S, Flint KH, Hawkins J, Harris WA, et al. Youth risk behavior surveillance-United States, 2013. MMWR. 2014;63(SS-4):1-168.

45. Agostinete RR, Lynch KR, Gobbo LA, Lima MC, Ito IH, Luizde-Marco R, et al. Basketball affects bone mineral density accrual in boys more than swimming and other impact sports: 9-mo follow-up. J Clin Densitom. 2016. https://doi.org/10.1016/j. jocd.2016.04.006 (Epub ahead of print).

46. Stanforth D, Lu T, Stults-Kolehmainen MA, Crim BN, Stanforth PR. Bone mineral content and density among female NCAA Division I athletes across the competitive season and over a multi-year time frame. J Strength Cond Res. 2014. https://doi. org/10.1519/jsc.0000000000000785 (Epub ahead of print).

47. Zribi A, Zouch M, Chaari H, Bouajina E, Zaouali M, Nebigh A, et al. Enhanced bone mass and physical fitness in prepubescent basketball players. J Clin Densitom. 2014;17(1):156-62.

48. Bagur-Calafat C, Farrerons-Minguella J, Girabent-Farrés M, Serra-Grima JR. The impact of high level basketball competition, calcium intake, menses, and hormone levels in adolescent bone density: a three-year follow-up. J Sports Med Phys Fitness. 2015;55(1-2):58-67.

49. Leigey D, Irrgang J, Francis K, Cohen P, Wright V. Participation in high-impact sports predicts bone mineral density in senior olympic athletes. Sports Health. 2009;1(6):508-13.

50. Perkins DL, Jacobs JJ, Barber BL, Eccles JL. Childhood and adolescent sports participation as predictors of participation in sports and physical fitness activities during young adulthood. Youth Soc. 2004;35(4):495-520.

51. Alfano CM, Klesges RC, Murray DM, Beech BM, McClanahan BS. History of sport participation in relation to obesity and related health behaviors in women. Prev Med. 2002;34(1):82-9.

52. Van Langendonck L, Lefevre J, Claessens AL, Thomis M, Philippaerts R, Delvaux K, et al. Influence of participation in highimpact sports during adolescence and adulthood on bone mineral density in middleaged men: a 27 -year follow-up study. Am J Epidemiol. 2003;158(6):525-33.

53. Van Mechelen W, Twisk J, Kemper H. The relationship between physical activity and physical fitness in youth and cardiovascular health later on in life. Int J Sports Med. 2002;23:S1-50.

54. Wijnstok NJ, Hoekstra T, van Mechelen W, Kemper HC, Twisk JW. Cohort profile: the Amsterdam Growth and Health Longitudinal Study. Int J Epidemiol. 2013;42(2):422-9.

55. Ames ME, Leadbeater BJ, MacDonald SWS. Health behavior changes in adolescence and young adulthood: implications for cardiometabolic risk. Health Psychol. 2018;37(2):103-13.

56. Appelqvist-Schmidlechner K, Vaara J, Häkkinen A, Vasankari T, Mäkinen J, et al. Relationships between youth sports participation and mental health in young adulthood among Finnish males. Am J Health Promot. 2017. https://doi.org/10.1177/0890117117 746336 (Epub ahead of print).

57. Comstock D, Currie DW, Pierpoint LA. Summary report: national high school sports-related injury surveillance study, 2014-15 school year. High school RIO study reports. http:// www.ucdenver.edu/academics/colleges/PublicHealth/research/ ResearchProjects/piper/projects/RIO/Pages/Study-Reports.aspx. Accessed 21 Jul 2016.

58. Roos KG, Marshall SW, Kerr ZY, Golightly YM, Kucera KL, Myers JB, et al. Epidemiology of overuse injuries in collegiate and high school athletics in the United States. Am J Sports Med. 2015;43(7):1790-7.

59. Barber Foss KD, Myer GD, Hewett TE. Epidemiology of basketball, soccer, and volleyball injuries in middle-school female athletes. Phys Sportsmed. 2014;42(2):146-53.

60. Emery CA, Meeuwisse WH, Hartmann SE. Evaluation of risk factors for injury in adolescent soccer. Implementation and validation of an injury surveillance system. Am J Sports Med. 2005;33:1882-91.

61. Ramirez M, Brown Schaffer B, Shen H, et al. Injuries to high school football athletes in California. Am J Sports Med. 2006;34:1147-58.

62. Buist I, Bredeweg SW, Lemmink KA, et al. Predictors of running-related injuries in novice runners enrolled in a systematic training program: a prospective cohort study. Am J Sports Med. 2010;38:273-80.

63. Tenforde AS, Barrack MT, Nattiv A, Fredericson M. Parallels with the female athlete triad in male athletes. Sports Med. 2016;46(2):171-82.

64. De Souza MJ, Nattiv A, Joy E, Misra M, Williams NI, Mallinson RJ, et al. 2014 Female Athlete Triad Coalition consensus statement on treatment and return to play of the female athlete triad: 1st International Conference held in San Francisco, CA, May 2012, and 2nd International Conference held in Indianapolis, IN, May 2013. Clin J Sport Med. 2014;24(2):96-119. 
65. Barrack MT, Gibbs JC, De Souza MJ, Williams NI, Nichols JF, Rauh MJ, et al. Higher incidence of bone stress injuries with increasing female athlete triad-related risk factors: a prospective multisite study of exercising girls and women. Am J Sports Med. 2014;42(4):949-58.

66. Rose MS, Emery CA, Meeuwisse WH. Sociodemographic predictors of sports injury in adolescents. Med Sci Sports Exerc. 2008;40:444-50.

67. Loud KJ, Gordon CM, Micheli LJ, et al. Correlates of stress fractures among preadolescent and adolescent girls. Pediatrics. 2005;115:e399-406.

68. Ohta-Fukushima M, Mutoh Y, Takasugi S, et al. Characteristics of stress fractures in young athletes under 20 years. J Sports Med Phys Fitness. 2002;42:198-206.

69. Borowski LA, Yard EE, Fields SK, Comstock RD. The epidemiology of US high school basketball injuries, 2005-2007. Am J Sports Med. 2008;36(12):2328-35.

70. Comstock D, Collins CL, McIlvain NM. Summary report, national high school sports-related injury surveillance study, 2010-2011 school year. http://www.nationwidechildrens.org/ Document/Get/103354. Accessed 17 Jan 2017.

71. LaPrade RF, Agel J, Baker J, Brenner JS, Cordasco FA, Côté J, et al. Early sport specialization consensus statement. Orthop J Sports Med. 2016;4(4):1-8.

72. Soligard T, Myklebust G, Steffen K, et al. Comprehensive warmup programme to prevent injuries in young female footballers: cluster randomised controlled trial. BMJ. 2008;337:a2469.

73. Steffen K, Myklebust G, Olsen OE, Holme I, Bahr R. Preventing injuries in female youth football-a cluster-randomized controlled trial. Scand J Med Sci Sports. 2008;18(5):605-14.

74. Tegnander A, Olsen OE, Moholdt TT, Engebretsen L, Bahr R. Injuries in Norwegian female elite soccer: a prospective one-season cohort study. Knee Surg Sports Traumatol Arthrosc. 2008;16(2):194-8.

75. van Beijsterveldt AM, Krist MR, Schmikli SL, et al. Effectiveness and cost-effectiveness of an injury prevention programme for adult male amateur soccer players: design of a cluster-randomised controlled trial. Inj Prev. 2011;17:1-5.

76. Longo UG, Loppini M, Berton A, et al. The FIFA 11+ program is effective in preventing injuries in elite male basketball players: a cluster randomized controlled trial. Am J Sports Med. 2012;40(5):996-1005.

77. LaBella CR, Huxford MR, Grissom J, Kim KY, Peng J, Christoffel KK. Effect of neuromuscular warm-up on injuries in female soccer and basketball athletes in urban public high schools: cluster randomized controlled trial. Arch Pediatr Adolesc Med. 2011;165(11):1033-40.

78. Emery CA, Rose MS, McAllister JR, Meeuwisse WH. A prevention strategy to reduce the incidence of injury in high school basketball: a cluster randomized controlled trial. Clin J Sport Med. 2007;17(1):17-24.

79. Cumps E, Verhagen E, Meeusen R. Efficacy of a sports specific balance training programme on the incidence of ankle sprains in basketball. J Sports Sci Med. 2007;6(2):212-9.

80. Petersen J, Thorborg K, Bachmann Nielsen M, Budtz-Jørgensen E, Hölmich P. Preventive effect of eccentric training on acute hamstring injuries in men's soccer: a cluster-randomized controlled trial. Am J Sports Med. 2011;39:2296-303.

81. Baker J, Côté J, Abernethy B. Sport-specific practice and the development of expert decision-making in team ball sports. $\mathbf{J}$ Appl Sport Psychol. 2003;15:12-25.

82. McCambridge TM, Stricker PR. Strength training by children and adolescents. Pediatrics. 2008;121:835-40.

83. Faigenbaum AD, Kraemer WJ, Blimkie CJ, et al. Youth resistance training: updated position statement paper from the National Strength and Conditioning Association. J Strength Cond Res. 2009;23(suppl 5):S60-79.
84. Faigenbaum AD, Myer GD. Resistance training among young athletes: safety, efficacy and injury prevention effects. Br J Sports Med. 2010;44:56-63.

85. Faigenbaum AD, Myer GD. Pediatric resistance training: benefits, concerns, and program design considerations. Curr Sports Med Rep. 2010;9:161-8.

86. Lloyd RS, Faigenbaum AD, Stone MH, et al. Position statement on youth resistance training: the 2014 International Consensus. Br J Sports Med. 2014;48(7):498-505.

87. Heidt RS Jr, Sweeterman LM, Carlonas RL, et al. Avoidance of soccer injuries with preseason conditioning. Am J Sports Med. 2000;28:659-62.

88. Cuff S, Loud K, O'Riordan MA. Overuse injuries in high school athletes. Clin Pediatr. 2010;49:731-6.

89. Bergeron MF, et al. International Olympic Committee consensus statement on youth athletic development. Br J Sports Med. 2015;49:843-51.

90. Myer GD, Jayanthi N, DiFiori JP, Faigenbaum AD, Kiefer AW, Logerstedt D, et al. Sport specialization, part I: does early sports specialization increase negative outcomes and reduce the opportunity for success in young athletes? Sports Health. 2015;7(5):437-42.

91. Ericsson KA, Krampe RT, Tesch-Römer C. The role of deliberate practice in the acquisition of expert performance. Psychol Rev. 1993;100(3):363-406.

92. Barreiros A, Côté J, Fonseca AM. From early to adult sport success: analysing athletes' progression in national squads. Eur J Sport Sci. 2014;14(Suppl 1):S178-82.

93. Schumacher YO, Mroz R, Mueller P, Schmid A, Ruecker G. Success in elite cycling: a prospective and retrospective analysis of race results. J Sports Sci. 2006;24(11):1149-56.

94. Brouwers J, De Bosscher V, Sotiriadou P. An examination of the importance of performances in youth and junior competition as an indicator of later success in tennis. Sport Man Rev. 2012;15:461-75

95. Davids K, Güllich A, Shuttleworth R, Araújo D. Understanding environmental and task constraints on talent development: analysis of micro-structure of practice and macro-structure of developmental histories. In: Baker J, Cobley S, Schorer J, Wattie $\mathrm{N}$, editors. The Routledge handbook of talent identification and development. New York: Routledge; 2016. p. 192-206.

96. Cathey RM. Retrospective practice histories of expert and novice baseball pitchers (Doctoral dissertation). University of South Carolina, Columbia. Available from ProQuest Dissertations and Theses database. 2010. [UMI No. 3413286].

97. Ford PR, Ward P, Hodges NJ, Williams AM. The role of deliberate practice and play in career progression in sport: the early engagement hypothesis. High Ability Stud. 2009;20:65-75.

98. Elferink-Gemser M, Visscher C, Lemmink AP, Mulder T. Multidimensional performance characteristics and standard of performance in talented youth field hockey players: a longitudinal study. J Sports Sci. 2006;25:481-9.

99. Ford PR, Williams AM. The developmental activities engaged in by elite youth soccer players who progressed to professional status compared to those who did not. Psychol Sport Exerc. 2012;13:349-52.

100. Haugaasen M, Jordet G. Developing football expertise: a football-specific research review. Int Rev Sport Exerc Psychol. 2012;5:177-201.

101. Ward P, Hodges NJ, Williams AM, Starkes JL. Deliberate practice and expert performance: defining the path to excellence. In: Williams AM, Hodges NJ, editors. Skill acquisition in sport: research, theory and practice. New York: Routledge; 2004. p. 231-58.

102. Weissensteiner J, Abernethy B, Farrow D, Müller S. The development of anticipation: a cross-sectional examination of the 
practice experiences contributing to skill in cricket batting. $\mathrm{J}$ Sport Exerc Psychol. 2008;30(6):663-84.

103. Moesch K, Elbe AM, Hauge M, Wikman JM. Late specialization: the key to success in centimeters, grams, or seconds (cgs) sports. Scand J Med Sci Sports. 2011;21(6):e282-90.

104. Moesch K, Hauge ML, Wikman JM, Elbe AM. Making it to the top in team sports: start later, intensify, and be determined. Talent Dev Excell. 2013;5(2):85-100.

105. Van Rossum JH. Deliberate practice and Dutch field hockey: an addendum to Starkes. Int J Sport Psychol. 2000;31:452-60.

106. Güllich A. Developmental sport activities of international medalists and non-medalists-a matched-pairs analysis. J Sports Sci. 2017;23:2281-8.

107. Butcher J, Lindner KJ, Johns DP. Withdrawal from competitive youth sport: a retrospective ten-year study. J Sport Behav. 2002;25:145-64.

108. Abernethy B, Baker J, Côté J. Transfer of pattern recall skills as a contributor to the development of sport expertise. Appl Cogn Psychol. 2005;19:705-18.

109. Loy SF, Hoffman JJ, Holland GJ. Benefits and practical use of cross-training in sports. Sports Med. 1995;19(1):1-8.

110. Schmidt RA, Wrisberg CA. Motor learning and performance: a problem-based learning approach. 4th ed. Champaign: Human Kinetics; 2008.

111. Smeeton NJ, Ward P, Williams AM. Do pattern recognition skills transfer across sports? A preliminary analysis. J Sports Sci. 2004;22(2):205-13.

112. Rea T, Lavallee D. An examination of athletes' experiences of the talent transfer process. Talent Dev Excell. 2015;7(1):41-67.

113. Bransford JD, Schwartz D. Rethinking transfer: a simple proposal with multiple implications. In: Iran-Nejad A, Pearson PD, editors. Review of research in education, vol. 24. Washington, DC: American Educational Research Association; 1999. p. 61-100.

114. Wolpert DM, Diedrichsen J, Flanagan JR. Principles of sensorimotor learning. Nat Rev Neurosci. 2011;12(12):739-51.

115. Masters RSW. Knowledge, knerves and know-how: the role of explicit versus implicit knowledge in the breakdown of a complex motor skill under pressure. Br J Psychol. 1992;83:343-8.

116. Maxwell JP, Masters RS, Eves FF. From novice to know-how: a longitudinal study of implicit motor learning. J Sports Sci. 2000;18(2):111-20.

117. Côté J, Horton S, MacDonald D, Wilkes S. The benefits of sampling sports during childhood. Phys Health Educ J. 2009;74:6-11.

118. Côté J, Lidor R, Hackfort D. ISSP position stand: to sample or to specialize? Seven postulates about youth sport activities that lead to continued participation and elite performance. Int J Sport Exerc Psychol. 2009;9:7-17.

119. Côté J, Vierimaa M. The developmental model of sport participation: 15 years after its first conceptualization. Sci Sports. 2014;29:S63-9.

120. Malina RM. Early sport specialization: roots, effectiveness, risks. Curr Sports Med Rep. 2010;9:364-71.

121. Feeley BT, Agel J, LaPrade RF. When is it too early for single sport specialization? Am J Sports Med. 2016;44(1):234-41.

122. Read PJ, Oliver JL, De Ste Croix MB, Myer GD, Lloyd RS. The scientific foundations and associated injury risks of early soccer specialisation. J Sports Sci. 2016;27:1-8.

123. Lloyd RS, Cronin JB, Faigenbaum AD, Haff GG, Howard R, Kraemer WJ, et al. National Strength and Conditioning Association position statement on long-term athletic development. J Strength Cond Res. 2016;30(6):1491-509.

124. Brenner JS. Council on Sports Medicine and Fitness. Sports specialization and intensive training in young athletes. Pediatrics. 2016;138(3):e1-8.
125. Gulbin J, Croser MJ, Morley EJ, Weissensteiner JR. An integrated framework for the optimisation of sport and athlete development: a practitioner approach. J Sports Sci. 2013;31(12):1319-39.

126. Weissensteiner JR. Method in the madness-working towards a viable 'paradigm' for better understanding and supporting the athlete pathway. In: Baker J, Cobley S, Schorer J, Wattie $\mathrm{N}$, editors. Routledge handbook of talent identification and development in sport. London: Routledge; 2017. p. 133-49.

127. Côté J, Fraser-Thomas J. Youth involvement and positive development in sport. In: Crocker PRE, editor. Sport psychology: a Canadian perspective. 3rd ed. Toronto: Pearson; 2016. p. 256-87.

128. Coutinho P, Mesquita I, Davids K, Fonseca AM, Côté J. How structured and unstructured activities aid the development of expertise in volleyball players. Psychol Sport Exerc. 2016;25:51-9.

129. Hansen DM, Larson RW. Amplifiers of developmental and negative experiences in organized activities: dosage, motivation, lead roles, and adult-youth ratios. J Appl Dev Psychol. 2007;28(4):360-74.

130. Hidi S, Renninger KA. The four-phase model of interest development. Educ Psychol. 2006;41(2):111-27.

131. Hulleman CS, Durik AM, Schweigert SA, Harackiewicz JM. Task values, achievement goals, and interest: an integrative analysis. J Educ Psychol. 2008;100:398-416.

132. Pearce N, Larson RW. How teens become engaged in youth development programs: the process of motivational change in a civic activism organization. Appl Dev Sci. 2006;10:121-31.

133. Ryan RM, Deci EL. Self-determination theory and the facilitation of intrinsic motivation, social development, and wellbeing. Am Psychol. 2000;55:68-78.

134. Smoll FL, Smith RE, Cumming SP. Effects of a motivational climate intervention for coaches on changes in young athletes' achievement goal orientations. J Clin Sport Psychol. 2007;1:23-46.

135. Côté J, Strachan L, Fraser-Thomas J. Participation, personal development, and performance through sport. In: Holt NL, editor. Positive youth development through sport. London: Routledge; 2008. p. 34-45.

136. Côté J, Erickson K. Diversification and deliberate play during the sampling years. In: Baker J, Farrow D, editors. The handbook of sport expertise. London: Routledge; 2015. p. 305-16.

137. Côté J, Turnnidge J, Evans MB. The dynamic process of development through sport. Kin Slov. 2014;20:14-26.

138. Côté J, Turnnidge J, Vierimaa M. A personal assets approach to youth sport. In: Smith A, Green K, editors. Handbook of youth sport. London: Routledge; 2016. p. 243-56.

139. Magill RA. Critical periods: relation to youth sports. In: Magill RA, editor. Children in sport human. Champaign: Kinetics Publishers, Inc; 1982. p. 38-47.

140. Weiss MR. A theoretical overview of competence motivation. In: Weiss MR, Gould D, editors. Sport for children and youths. Champaign: Human Kinetics Publishers Inc; 1986. p. 75-88.

141. Imtiaz F, Hancock DJ, Côté J. Examining young recreational male soccer players' experience in adult- and peer-led structures. Res Q Exerc Sport. 2016;17:1-10.

142. Malina RM, Rogol AD, Cumming SP, Coelho e Silva MJ, Figueiredo AJ. Biological maturation of youth athletes: assessment and implications. Br J Sports Med. 2015;49:852-9.

143. Gould D. Understanding attrition in children's sport. In: Gould D, Weiss MR, editors. Advances in pediatric sport sciences. Champaign: Human Kinetics Publishers, Inc; 1987. p. 61-86.

144. Malina RM. Readiness for competitive youth sport Chapter 7. In: Weiss MR, Gould D, editors. Sport for children and youths. Champaign: Human Kinetics Publishers, Inc; 1986. p. 45-50. 
145. Aicinena S. Youth sport readiness: a predictive model for success. Phys Educator. 1992;49:58-67.

146. Jr. NBA Flagship Network. 2018. https://jr.nba.com/jr-nbaflagship-network/. Accessed 17 Jan 2017.

147. Güllich A, Cobley S. On the efficacy of talent identification and talent development programmes. In: Baker J, Cobley S, Schorer J, Wattie N, editors. The Routledge handbook of talent identification and development in sport. New York: Routledge; 2017. p. 80-98.

148. Paruthi S, Brooks LJ, D’Ambrosio C, Hall WA, Kotagal S, Lloyd RM, et al. Concensus statement of the American Academy of Sleep Medicine on the recommended amount of sleep for healthy children: methodology and discussion. J Clin Sleep Med. 2016;12(11):1549-61. 